\title{
Analisis Faktor Determinan yang Mempengaruhi Sikap WUS Dalam Menggunakan AKDR Di Puskesmas Pesantren II Kota Kediri
}

\author{
Margaretha Loy, Lingga Kusuma Wardani*, Anggrawati Wulandari \\ Institut Ilmu Kesehatan STRADA Indonesia \\ Corresponding author: Lingga Kusuma Wardani (linggakusumawardani@gmail.com) \\ Received: December, 16 2019; Accepted: January, 19 2020; Published: March, 152020
}

\begin{abstract}
ABSTRAK
Kebanyakan WUS lebih memilih menggunakan kontrasepsi hormonal, dikarenakan Alat Kontrasepsi Dalam Rahim (AKDR) merupakan benda padat yang apabila dipasang dalam cavitas uteri dapat menyebabkan perubahan endometrium uterus sehingga menganggu implantasi ovum.

Hasil menunjukkan sebagian besar responden memiliki pengetahuan cukup, yaitu 25 responden $(56,8 \%)$, sebagian besar responden memiliki persepsi negatif, yaitu 24 responden $(54,5 \%)$, serta sebagian besar responden memiliki dukungan suami tidak mendukung, yaitu 26 responden $(59,1 \%)$ dan sebagian besar responden memiliki sikap negatif, yaitu 30 responden $(68,2 \%)$. Hasil uji regresi logistic menunjukkan adapengaruh pengetahuan terhadap sikap WUS dalam menggunakan kontrasepsi AKDR di Wilayah Kerja Puskesmas Pesantren II Kota Kediri dengan p-value $=0,048<\mathrm{a}=0,05$.

Berdasarkan kondisi ini maka sikap responden terhadap keuntungan AKDR sangat dipengaruhi oleh kognisinya, artinya setiap informasi yang diterima oleh responden akan menjadi alat bagi responden un.tuk menentukan sikapnya tentang AKDR tersebut.
\end{abstract}

Kata Kunci: Pengetahuan, Kunjungan Kelas Ibu Hamil, Purposive Sampling

This is an open-acces article distributed under the terms of the Creative Commons Attribution-ShareAlike 4.0 International License.

\section{PENDAHULUAN}

Alat Kontrasepsi Dalam Rahim (AKDR) merupakan benda padat yang apabila dipasang dalam cavitas uteri dapat menyebabkan perubahan endometrium uterus sehingga menganggu implantasi ovum. AKDR yang mengandung tembaga $(\mathrm{Cu})$ juga menghambat khasiat anhidrase, karbon dan fosfatase alkali, memblok bersatunya sperma dan ovum, mengurangi jumlah sperma yang mencapai tuba fallopii dan menginaktifkan sperma (Kusmiran, 2010). AKDR dikatakan efektif karena hanya memerlukan 1 kali pemasangan dan dapat dibiarkan selama bertahun tahun, aman karena dapat mencegah kehamilan dalam jangka waktu yang lama (Manuaba, 2010). AKDR memiliki karakteristik yang berbeda dengan alat kontrasepsi lainnya dimana masa penggunaannya yang cukup lama yaitu hingga 10 tahun. Kebanyakan WUS lebih memilih menggunakan kontrasepsi hormonal, padahal penggunaan kontrasepsi hormonal dalam jangka waktu lama dapat berakibat pada terjadinya penurunan fertilitas, walaupun penggunaannya sudah dihentikan (Hartanto, 2014).

Di Indonesia pencapaian pasangan usia subur (PUS) pada tahun 2017 sebanyak 45.905 .815 dengan peserta KB aktif $34.872 .054(75,96 \%)$ yang terdiri dari peserta KB suntik sebanyak 16.203 .682 
(46,37\%), peserta KB pil sebanyak 9.000.384 (25,81\%), peserta KB AKDR 3.933.631 (11,28\%), peserta KB implant sebanyak 3.077.417 (8,82\%), peserta KB MOW sebanyak 1.216.351 (3,49\%), peserta KB kondom sebanyak 1.032.033 (2,96\%) dan peserta KB MOP sebanyak $248.685(0,71 \%)$ (BKKBN, 2017).

Data di Puskesmas Pesantren II Kota Kediri pada tahun 2018 terdapat 4.947 peserta KB aktif yang terdiri dari peserta KB AKDR 298 peserta (6,6\%), KB MOP 10 peserta (0,2\%), KB MOW 396 peserta $(8,0 \%)$, KB implan 282 peserta (5,7\%), Kondom 272 peserta (5,5\%), KB suntik 2.894 peserta $(58,5 \%)$ dan KB pil 772 peserta (15,6\%) (Puskesmas Pesantren II, 2019). Hasil studi pendahuluan melalui wawancara terhadap 10 akseptor KB selain AKDR didapatkan bahwa 10 orang tidak menggunakan memilih AKDR karena khawatir penggunaan AKDR menimbulkan rasa sakit saat proses pemasangan dan menyebabkan ketidaknyamanan saat melakukan hubungan suami istri. Selain itu 7 orang $(70 \%)$ memandang penggunaan AKDR sulit hamil kembali dan 3 orang (30\%) merasa harga AKDR terlalu mahal jika tidak memiliki kartu BPJS.

Rendahnya penggunaan alat kontrasepsi AKDR tersebut disebabkan oleh banyaknya rumor negatif tentang alat kontrasepsi sehingga mempengaruhi sikap calon akseptor dalam memilih alat kontrasepsi. Sikap negatif disebabkan oleh rumor negatif, diantaranya adalah ada anggapan bahwa AKDR tidak reversible. Menurut Hanafiah (2005:28) penggunaan AKDR dikawatirkan tidak bisa hamil kembali, selain itu AKDR juga dipersepsikan dapat menyebabkan timbulnya rasa sakit pada saat senggama sehingga dapat menyebabkan terjadinya ketidak harmonisan rumah tangga.

Untuk meningkatkan sikap positif pasangan usia subur terhadap AKDR perlu dilaksanakan peningkatan sosialisasi kontrasepsi AKDR melalui konseling pra penggunaan alat kontrasepsi, karena selama ini proses sosialisasi hanya dilakukan pada waktu-waktu tertentu misalnya safari $\mathrm{KB}$, sedangkan sosialisasi secara reguler misalnya melalui penyuluhan pada saat arisan / pertemuan warga belum dilaksanakan. Kelebihan AKDR yang dapat dipergunakan dalam jangka waktu yang panjang serta proses perawatan yang mudah merupakan pilihan yang sesuai bagi wanita usia subur yang akan mengakhiri masa reproduktif atau menjarangkan jumlah anak $>5$ tahun. Sifat AKDR yang reversible serta tidak menurunkan fertilitas setelah alat dilepas seharusnya dapat dijadikan referensi bagi pasangan usia subur untuk menggunakan alat kontrasepsi AKDR (Hartanto, 2014).

Pemberian konseling ini dilaksanakan dalam 3 tahap yaitu konseling pada pra pemasangan, menjelang pemasangan dan selama masa penggunaan. Selain melalui konseling, meningkatkan keterlibatan suami dalam pemilihan alat kontrasepsi akan dapat memunculkan dukungan suami dalam penggunaan alat kontrasepsi AKDR sehingga dapat mendorong sikap positif dari WUS terhadap AKDR (Haryanti, 2011).

\section{BAHAN DAN METODE}

Penelitian analitik korelasional pendekatan cross sectionaldilakukan terhadap 44 wanita usia subur yang mendapatkan pelayanan KB di Puskesmas Pesantren II Kota Kediri menggunakan teknik simple random sampling. Pengumpulan data menggunakan kuesioner dengan Analisis data menggunakan uji Regresi logistic pada $\alpha=0,05$.

\section{HASIL PENELITIAN}

Karakteristik Subyek

Tabel 1. Karakteristik responden dalam penelitian ini meliputi usia, pendidikan, pekerjaan, informasi, pengetahuan, persepsi, dukungan suami dan sikap.

\begin{tabular}{llll}
\hline No & Karakteristik & $\mathbf{\Sigma N}$ & $\mathbf{\Sigma \%}$ \\
\hline 1 & Usia (tahun) & & \\
& $20-35$ & 25 & 57 \\
& $36-45$ & 19 & 43 \\
\hline 2 & Pendidikan & & \\
& Tidak & 2 & 4 \\
& Dasar & 23 & 52 \\
& Menengah & 17 & 39 \\
& Tinggi & 2 & 5 \\
\hline
\end{tabular}




\begin{tabular}{llll}
\hline 3 & Pekerjaan & 17 & 39 \\
& IRT & 14 & 32 \\
& Swasta & 13 & 29 \\
\hline \multirow{2}{*}{ Wiraswasta } & Informasi & & \\
& Belum pernah & 3 & 7 \\
& Pernah, tenaga kes & 28 & 64 \\
& Pernah, keluarga & 8 & 18 \\
& Pernah, media massa & 5 & 11 \\
\hline 5 & Pengetahuan & & \\
& Kurang & 7 & 15,9 \\
& Cukup & 25 & 56,8 \\
& baik & 12 & 27,3 \\
\hline 6 & Persepsi & & \\
& Negatif & 24 & 54,5 \\
& Positif & 20 & 45,5 \\
\hline 7 & Dukungan suami & & \\
& Tudak & 26 & 59,1 \\
& ya & 18 & 40,9 \\
\hline 8 & Sikap & & \\
& Negatif & 30 & 68,2 \\
& Positif & 14 & 31,8 \\
\hline & Total & $\mathbf{4 4}$ & $\mathbf{1 0 0}$ \\
\hline
\end{tabular}

\section{ANALISA DATA}

Tabel 2. Hasil Analisis Faktor Determinan Yang Mempengaruhi Sikap WUS Dalam Menggunakan Kontrasepsi AKDR di Wilayah Kerja Puskesmas Pesantren II Kota Kediri Tanggal 16-27 Mei 2019

\begin{tabular}{lcrrr} 
& B & S.E. & Sig. & \multicolumn{1}{c}{$\operatorname{Exp(B)}$} \\
\hline Pengetahuan & 1.513 & .969 & .048 & 3.539 \\
Persepsi & 3.431 & 1.473 & .020 & 5.909 \\
Dukungan & 2.130 & 1.236 & .032 & 4.416 \\
\hline
\end{tabular}

Hasil analisis pada table 2 dapat diinterpretasikan sebagai berikut:

1. Variabel pengetahuan diperoleh $p$-value $=0,048<\alpha=0,05$ maka H0 ditolak dan H1 diterima yang berarti ada pengaruh pengetahuan terhadap sikap WUS dalam menggunakan kontrasepsi AKDR di Wilayah Kerja Puskesmas Pesantren II Kota Kediri.

2. Variabel persepsi diperoleh $p$-value $=0,020<\alpha=0,05$ maka H0 ditolak dan H1 diterima yang berarti ada pengaruh persepsi terhadap sikap WUS dalam menggunakan kontrasepsi AKDR di Wilayah Kerja Puskesmas Pesantren II Kota Kediri.

3. Variabel dukungan suami diperoleh $p$-value $=0,032<\alpha=0,05$ maka $\mathrm{H} 0$ ditolak dan $\mathrm{H} 1$ diterima yang berarti ada pengaruh dukungan suami terhadap sikap WUS dalam menggunakan kontrasepsi AKDR di Wilayah Kerja Puskesmas Pesantren II Kota Kediri.

4. Faktor yang paling dominan dalam mempengaruhi sikap WUS dalam penggunaan kontraspei AKDR adalah faktor persepsi, dengan koefisien $\beta$ tertinggi yaitu 3,431.

\section{PEMBAHASAN}

Pengaruh pengetahuan terhadap sikap WUS dalam menggunakan kontrasepsi AKDR di Wilayah Kerja Puskesmas Pesantren II Kota Kediri

Hasil analisis menunjukkan variabel pengetahuan diperoleh $p$-value $=0,048<\alpha=0,05$ maka H0 ditolak dan H1 diterima yang berarti ada pengaruh pengetahuan terhadap sikap WUS dalam menggunakan kontrasepsi AKDR di Wilayah Kerja Puskesmas Pesantren II. Pengetahuan WUS tentang kontrasepsi 
AKDR diketahui bahwa sebagian besar responden memiliki pengetahuan dalam kategori cukup, yaitu 25 responden $(56,8 \%)$. Berdasarkan data umum diketahui sebagian besar dari responden berpendidikan dasar (SD, SMP), yaitu 23 responden (52\%) sedangkan hasil tabulasi silang diketahui bahwa responden dengan pengetahuan cukup memiliki sikap terhadap kontrasepsi AKDR dalam kategori negatif, yaitu 20 responden $(45,5 \%)$. Hasil analisis kuesioner diketahui pertanyaan dengan skor terendah adalah nomor 11 tentang pengaruh penggunaan AKDR terhadap hubungan seksual.

Hasil penelitian menunjukkan bahwa sebagian besar pengetahuan responden kategori cukup. Dalam kategori cukup berarti responden tidak mengetahui detail dari kontrasepsi AKDR, pada umumnya WUS mengidentikkan AKDR dengan sebutan spiral yaitu alat kontrasepsi yang dimasukkan dalam mulut rahim. Informasi yang disampaikan dari mulut ke mulut merupakan salah satu faktor yang menjadi pertimbangan WUS dalam menggunakan alat kontrasepsi AKDR. Apabila informasi tentang efek negatif dan mitos tentang AKDR yang lebih sering beredar dimasyarakat dan tidak sebanding dengan penyuluhan manfaat kontrasepsi AKDR, hal ini akan mengakibatkan masyarakat semakin menjauh dan menyikapi AKDR sebagai kontrasepsi yang kurang baik.

\section{Pengaruh persepsi terhadap sikap WUS dalam menggunakan kontrasepsi AKDR di Wilayah Kerja Puskesmas Pesantren II Kota Kediri}

Hasil analisis menunjukkan variabel persepsi diperoleh $p$-value $=0,020<\alpha=0,05$ maka $\mathrm{H} 0$ ditolak dan H1 diterima yang berarti ada pengaruh persepsi terhadap sikap WUS dalam menggunakan kontrasepsi AKDR di Wilayah Kerja Puskesmas Pesantren II. Persepsi WUS tentang kontrasepsi AKDR diketahui bahwa sebagian besar responden memiliki persepsi dalam kategori negatif, yaitu 24 responden $(54,5 \%)$. Hasil tabulasi silang diketahui bahwa responden dengan persepsi negatif memiliki sikap terhadap kontrasepsi AKDR dalam kategori negatif, yaitu 23 responden (52,3\%). Hasil analisis kuesioner menunjukkan bahwa pertanyaan dengan skor terendah terdapat pada soal nomor 4 terkait penggunaan AKDR terhadap hubungan seksual.

Hasil penelitian menunjukkan bahwa sebagian besar responden memiliki persepsi tentang AKDR dalam kategori negatif dan memiliki pengaruh yang signifikan terhadap sikap penggunaan AKDR. Penilaian seseorang dalam hal ini persepi, akan membentuk dan mempengaruhi penghayatan terhadap informasi yang diterima. Persepsi selanjutnya akan menjadi salah satu dasar terbentuknya sikap. Keputusan akhir apakah persepsi tersebut akan membentuk sikap positif atau negatif tergantung dari berbagai faktor eksternal yang dapat mempengaruhinya misalnya saja faktor dukungan dari keluarga. Apabila dukungan dari keluarga terdekat selaras dengan persepsi yang dimiliki maka akan menguatkan sikap yang akan terbentuk.

\section{Pengaruh dukungan suami terhadap sikap WUS dalam menggunakan kontrasepsi AKDR di Wilayah Kerja Puskesmas Pesantren II Kota Kediri}

Hasil analiis menunjukkan variabel dukungan suami diperoleh $p$-value $=0,032<\alpha=0,05$ maka $\mathrm{H} 0$ ditolak dan $\mathrm{H} 1$ diterima yang berarti ada pengaruh dukungan suami terhadap sikap WUS dalam menggunakan kontrasepsi AKDR di Wilayah Kerja Puskesmas Pesantren II. Dukungan suami terhadap penggunaan kontrasepsi AKDR diketahui bahwa sebagian besar responden tidak mendapatkan dukungan suami, yaitu 26 responden $(59,1 \%)$. Hasil analisis kuesioner menunjukkan bahwa pertanyaan dengan skor terendah terdapat pada soal nomor 12 yaitu dukungan suami terhadap penggunaan AKDR.

Dalam melaksanakan keluarga berencana, dukungan suami sangat diperlukan, seperti diketahui bahwa di Indonesia, keputusan suami dalam mengizinkan istri adalah pedoman penting bagi istri untuk menggunakan alat kontrasepsi.Bila suami tidak mengizinkan atau mendukung, hanya sedikit istri yang berani untuk tetap memasang alat kontrasepsi tersebut.Dukungan suami sangat berpengaruh besar dalam pengambilan keputusan karena dipengaruhi oleh faktor sosial budaya (Suparyanto, 2011). Sedangkan hasil penelitian Imroni (2012) menyebutkan bahwa ada hubungan signifikan antara faktor dukungan suami terhadap pemilihan jenis kontrasepsi implan. Dukungan merupakan bantuan atau dukungan yang diterima individu dari orang-orang tertentu dalam kehidupannya yang dapat membuat penerima merasa diperhatikan, dihargai dan dicintai. Sedangkan dukungan keluarga merupakan salah satu jenis dari dukungan sosial, interaksi timbal balik antara individu atau anggota keluarga dapat menimbulkan hubungan ketergantungan satu sama lain. Menurut penelitian Wardani (2013), suami dalam keluarga di Indoensia merupakan sosok yang memiliki peran utama dalam menentukan segala 
hal yang terkait dengan keluarga misalnya adalah dalam penentuan alat kontrasepsi, keputusan keluarga khususnya suami akan lebih kuat dibandingkan dengan pendapat ibu atau istri. Peran dan tanggung jawab keluarga dalam kesehatan reproduksi berpengaruh terhadap pemeliharaan kesehatan dan kelangsungan hidup ibu dan anak, serta berperilaku seksual yang sehat dan aman bagi dirinya, istri, dan keluarganya.

Faktor yang paling mempengaruhi sikap WUS dalam menggunakan kontrasepsi AKDR di Wilayah Kerja Puskesmas Pesantren II Kota Kediri.

Faktor yang paling dominan dalam mempengaruhi sikap WUS dalam penggunaan kontraspei AKDR adalah faktor persepsi, dengan koefisien $\beta$ tertinggi yaitu 3,431. Hasil analisis kuesioner diketahui pertanyaan dengan skor terendah adalah nomor 5 terkait efek samping hormonal dari kontrasepsi AKDR.

Sikap merupakan hasil dari proses penerimaan informasi untuk dipahami. Alat untuk memperoleh informasi tersebut adalah penginderaan (penglihatan, pendengaran, atau peraba), sedangkan alat untuk memahaminya adalah kesadaran atau kognisi (Azwar, 2014).Menurut Ayele, dkk. (2012) mengemukakan bahwa seseorang yang memiliki persepsi negatif terhadap suatu hal cenderung akan menunjukkan sikap dan perilaku yang negatif pula terhadap upaya perawatan diri maupun pencegahan penyakit, begitu pula sebaliknya. Robbin (2013) menambahkan persepsi sebagai proses dimana seseorang mengorganisasikan dan menginterpretasikan sensasi yang di rasakan dengan tujuan untuk memberi makna terhadap lingkungannya.Hasil penelitian menunjukkan bahwa persepsi merupakan faktor yang paling dominan dalam mempengaruhi sikap WUS dalam penggunaan AKDR. Persepsi merupakan tingkatan kedua setelah pengetahuan dalam urutan teori perubahan perilaku manusia. Dalam hal peneltiian ini, setelah memiliki pengetahuan tentang AKDR, WUS mempersepsikan AKDR sesuai dengan apa yang ia ketahui. Apabila pengetahuan yang dimiliki terbatas atau bahkan salah maka akan timbul persepsi negati yang selanjutnya menimbulkan sikap yang negatif pul. Berdasarkan kondisi ini maka sikap responden terhadap keuntungan AKDR sangat dipengaruhi oleh kognisinya, artinya setiap informasi yang diterima oleh responden akan menjadi alat bagi responden untuk menentukan sikapnya tentang AKDR tersebut.

\section{KESIMPULAN DAN SARAN}

\section{Kesimpulan}

1. Adapengaruh pengetahuan terhadap sikap WUS dalam menggunakan kontrasepsi AKDR di Wilayah Kerja Puskesmas Pesantren II Kota Kediri dengan $p$-value $=0,048<\alpha=0,05$.

2. Adapengaruh persepsi terhadap sikap WUS dalam menggunakan kontrasepsi AKDR di Wilayah Kerja Puskesmas Pesantren II Kota Kediri dengan $p$-value $=0,020<\alpha=0,05$.

3. Adapengaruh dukungan suami terhadap sikap WUS dalam menggunakan kontrasepsi AKDR di Wilayah Kerja Puskesmas Pesantren II Kota Kediri dengan $p$-value $=0,032<\alpha=0,05$.

4. Faktor yang paling dominan dalam mempengaruhi sikap WUS dalam penggunaan kontraspei AKDR adalah faktor persepsi, dengan koefisien $\beta$ tertinggi yaitu 3,431

\section{Saran}

1. Bagi Responden

Diharapkan untuk menambah pengetahuannya tentang alat kontrasepsi AKDR dengan secara aktif bertanya pada petugas kesehatan saat konseling KB maupun melalui media massa internet, selain itu juga diharapkan untuk bertanya pada pengguna kontrasepsi AKDR tentang hal positif dan negatif dari pemakaian AKDR sehingga dapat menentukan sikap yang lebih positif terhadap kontrasepsi AKDR.

2. Bagi Institusi Kesehatan

Diharapkan dapat meningkatkan promosi kesehatan terkait alat kontrasepsi AKDR melalui kegiatan penyuluhan serta konseling yang lebih efekti misalnya menggunakan media yang menarik seperti video dalam rangka mensukseskan program pemerintah melalui program Keluarga Berencana (KB).

3. Bagi Peneliti Selanjutnya 
Diharapkan dapat mengembangkan penelitian ini dengan melakukan intervensi yang mengenai pemilihan AKDR pada WUS misalnya memberikan penyuluhan.

\section{REFERENSI}

BKKBN. 2014. Buku Pegangan Penyuluh Keluarga Berencana. Jakarta

Handayani. 2010. Buku Ajar Pelayanan Keluarga Berencana. Jakarta: Pustaka Rihama

Harahap, Y.N. 2011. Pengaruh Budaya Akseptor KB Terhadap Penggunaan Kontrasepsi IUD di Kecamatan Labu Kabupaten Deli Serdang. Medan: Jurnal Universitas Sumatera Utara.

Hartanto, Hanafi. 2014. Keluarga Berencana dan Kontrasepsi. Jakarta: Pustaka Sinar Harapan

Irwanto. 2015. Psikologi Umum. Jakarta : PT. Gramedia Pustaka Utama

Prawirohardjo. S. 2010.Ilmu Kebidanan. Edisi 4. Jakarta : P.T Bina Pustaka Sarwono Purwirohardjo.

Said, N.B.R. 2017. Pengaruh Faktor Dukungan Suami Terhadap Keikutsertaan Wanita Pasangan Usia Subur Dalam Penggunaan Alat Kontrasepsi Dalam Rahim (AKDR) di Desa Mangga Dua Kecamatan Tanjung Beringin Tahun 2017. Medan: Jurnal Universitas Sumatera Utara.

Saifuddin, Abdul Bari. 2016. Pelayanan Kesehatan Maternal \& Neonatal. Jakarta : Yayasan Bina. Pustaka Sarwono Prawirohardjo

Saleha, Sitti. 2014. Asuhan Kebidanan Pada Masa Nifas. Jakarta : Salamba Medika.

Satriyandari, Y. 2018. Gambaran Dukungan Suami Pada Pasangan Usia Subur Dengan Kejadian Unmetneed Di Kelurahan Panembahan Yogyakarta Tahun 2016. Jurnal Ilmiah Bidan, Vol.III, No.1, 2018.

Siyamti. 2014. Pengaruh Penyuluhan Tentang KB IUD (Intra Uterine Device) Terhadap Pengetahuan Tentang KB IUD Pada Ibu Di BPS Ny. Siti Fatimah Amd.Keb Desa Dukuh Kecamatan Ngadiluwih Kabupaten Kediri. Jurnal Kebidanan STIKes Surya Mitra Husada Kediri.

Sulistyawati, Ari. 2011. Pelayanan Keluarga Berencana. Jakarta: Salemba Medika.

Widayatun. Tri. Rusmi. 2016. Ilmu Prilaku. Jakarta : Sagung Seto. 